\title{
An overview of conflict in Africa in 2014
}

\section{Shirley de Villiers}

Shirley de Villiers is a lecturer and DPhil candidate in the University of Pretoria's Political Sciences Department (shirley.devilliers@up.ac.za

Violent conflict escalated in Africa in 2014, with five sub-Saharan states - the Central African Republic (CAR), Nigeria, Somalia, South Sudan and Sudan - accounting for an estimated $75 \%$ of all conflict-related deaths on the continent. This paper provides an overview of the five major sub-Saharan African conflicts in 2014 and considers the underlying causes and dynamics in the Seleka/anti-Balaka conflict in the CAR, the Islamist threats of Boko Haram and al-Shabaab in Nigeria and Somalia, the civil war in South Sudan, and the long-running conflict between Sudan's government and southern and Darfuri rebels. The paper unpacks the general trends evident in these conflicts and the implications for the settlement thereof, including the targeting of civilians, ethnic and religious mobilisation and the state as epicentre of violence. The paper concludes with a brief look ahead to 2015.

Keywords: Africa, conflict, CAR, Nigeria, Somalia, South Sudan, Sudan, Boko Haram, al-Shabaab

\section{Introduction}

Violent conflict escalated in Africa in 2014, with five countries in sub-Saharan Africa - the Central African Republic (CAR), Nigeria, Somalia, South Sudan and Sudan - accounting for an estimated $75 \%$ of all conflict-related deaths on the continent. ${ }^{1}$

According to the conflict-mapping think tank Armed Conflict and Location Event Data Project (ACLED), Nigeria proved to be the deadliest country in Africa, with 11360 fatalities ( $29 \%$ of the total), followed by South Sudan (6 383, accounting for 16\%). Somalia accounted for 4425 deaths (11\%), Sudan for $3888(10 \%)$ and the CAR, where the rate of violence virtually doubled from 2013 , accounted for $3282(8.5 \%){ }^{2}$

Civilians have borne the brunt of the conflicts, with levels of violence against non-combatants increasing for the first time in five years. ${ }^{3}$ Attacks on civilians accounted for $35 \%$ of conflictrelated fatalities, with populations in the CAR, Nigeria, Somalia and Sudan particularly at risk. ${ }^{4}$ Rebel and militia groups claimed 7900 civilian lives (67\% of the total): Nigerian Islamist group Boko Haram alone is said to be responsible for 3428 civilian deaths, while rebel factions Seleka and the anti-Balaka in the CAR are said to be responsible for 1599 reported civilian deaths. ${ }^{5}$ 
In all five conflicts, non-combatants, specifically targeted by all warring parties, have been victims of war crimes and crimes against humanity. These include sexual violence, extrajudicial killings, indiscriminate killings in aerial bombardments, and the destruction of property and livelihoods, often affecting food supplies. The recruitment of children into armed forces has also been pervasive.

This paper provides an overview of the five major sub-Saharan African conflicts in 2014 and considers the underlying causes and dynamics in the Seleka/anti-Balaka conflict in the CAR, the Islamist threats of Boko Haram and al-Shabaab in Nigeria and Somalia, the civil war in South Sudan, and the long-running conflict between Sudan's government and southern and Darfuri rebels. The paper unpacks the general trends evident in these conflicts and the implications for the settlement thereof, including the targeting of civilians, ethnic and religious mobilisation and the state as epicentre of violence. The paper concludes with a brief look ahead to 2015 .

\section{Major conflicts in sub-Saharan Africa}

\section{Political access}

The largely political underpinnings of the conflicts in the CAR, South Sudan and Sudan leadership struggles, political marginalisation, and demands for equitable political access resulted in an escalation in violence in 2014, with civilians often targeted on ethnic or religious grounds. A lack of political will and inability to reach consensus around issues of governance has obstructed peace efforts in all three cases.

\section{Seleka and anti-Balaka in the CAR}

In the CAR, the conflict that began in late 2012 with the mostly Muslim Seleka rebel group's march on Bangui and subsequent coup d'état - a coup brought on by poor governance, inequitable division of proceeds from natural resources, poor territorial extension of state authority and marginalisation of the state's mostly northern Muslim population - morphed into a bloody religious war.

Subsequent to coming to power, Seleka carried out attacks targeting non-Muslim civilians in the country. The predominantly Christian anti-Balaka, formed in response, began its own campaign of violence against Muslim civilians in late 2013. Unable to control his foot soldiers and under pressure from the international community - Seleka president Michel Djotodia resigned in January, leaving former Bangui mayor Catherine Samba-Panza to lead a weak transitional government until the 2015 elections.

The violence sparked by the 2013 coup has had a devastating effect on the civilian population. By January 2015, about 1 million of the country's 4,6 million population had fled, and 2,7 million were in need of humanitarian assistance. Insecurity had also affected livelihoods and agricultural production, leaving an estimated 1,5 million in need of emergency food aid. ${ }^{6}$

As Muslim and Christian armed groups targeted civilians based on religious affiliation and with the inter-communal violence this fomented - the country's Muslim population was decimated. It is estimated that about 450000 had fled the country by the end of the year, and by March Bangui's Muslim population had fallen from about 10000 to just $2400{ }^{7}$ Roughly 20000 of the country's remaining Muslims are ring-fenced into just nine locations in the 
central and western regions of the country, ${ }^{8}$ with anti-Balaka threatening violence if they leave, and preventing inflows of food and other aid.

Seleka-anti-Balaka hostility has also inflamed longstanding tensions between pastoralists and farming communities. Muslim Fulani pastoralists came under attack because of their supposed affiliation with Seleka (some indigent Fulani youths joined the rebel group), ${ }^{9}$ and retaliatory attacks unleashed a cycle of communal bloodshed.

The peace process in the CAR has had limited success. In early July, the International Contact Group for the CAR outlined a blueprint for resolution. At talks in Congo-Brazzaville later that month, Seleka, represented by Mohamed Dhaffane, pushed for a formal partition of the country. With that not forthcoming, Dhaffane acceded to a ceasefire on $23 \mathrm{July},{ }^{10}$ which was revoked by the group's hard-line military leader, Joseph Zindeko, a day later, and fighting resumed. ${ }^{11}$

The failed ceasefire speaks to a broader issue regarding resolution of the conflict: factionalism within the rebel groups makes it difficult to reach a settlement and to ensure compliance within groups.

Seleka has split into Bangui and north-eastern factions; the former is willing to negotiate, while the latter is pushing for a formal partition of the country. North-eastern leaders Nourredine Adam and Djotodia are unlikely to accept anything less: with international sanctions standing in the way of reclaiming authority in Bangui, they will be better positioned to shore up power and resources in an independent territory. ${ }^{12}$

Anti-Balaka, too, is a divided organisation. In a show of political expedience ahead of the July negotiations, two primary factions, led by Edouard Ngaissona and Sébastien Wenezoui, came together in order to consolidate control of Bangui and secure positions in a new government, but split soon after. ${ }^{13}$ The movement in the south-west of the country comprises local armed groups with their own leadership and no political representation. These groups do not take orders from leaders in Bangui, ${ }^{14}$ thus making implementation of agreements and enforcement difficult.

Elections for a democratic government are expected to take place in 2015. These have been pushed back to August from February as a result of insecurity and disagreement on issues such as voter registration. ${ }^{15}$ The political process does, however, show signs of moving forwards: the Bangui Forum on National Reconciliation is set to consider issues such as demobilisation, disarmament and reintegration of combatants in early 2015. A number of Seleka and antiBalaka have agreed to support the forum, but with factionalism rife in both movements, it is unclear what the broader buy-in to the process will be.

\section{The SPLM and the SPLM/A In Opposition in South Sudan}

In late 2013 months of political wrangling, leadership disputes and factionalism in the ruling Sudan People's Liberation Movement (SPLM) plunged Africa's newest state into civil war. On 15 December tensions between President Salva Kiir and his vice president and party deputy Riek Machar spilled over into open conflict between armed factions loyal to Kiir, of the Dinka ethnic group, and the Nuer Machar.

Conflict between Dinka and Nuer broke out in the country's capital, Juba, within hours of Machar and senior members of the SPLM's primary decision-making organ, the Political Bureau, boycotting the final day of the party's National Liberation Council, accusing Kiir of authoritarian leadership tendencies. The move led to a definitive split in the SPLM, with Kiir accusing Machar of orchestrating a coup, and subsequently instituting charges of treason 
against him. Machar announced himself leader of an armed opposition, the SPLM/Army In Opposition (SPLM/A-IO), committed to toppling Kiir through force.

In the months preceding the split, Kiir had initiated something of a political purge: presidential hopeful Machar was dismissed as the state's vice president; most of Kiir's cabinet was replaced, in some cases by newcomers supportive of Khartoum's hated National Congress Party (NCP); and party Secretary-General Pagan Amum Okiech was suspended pending an investigation into corruption. ${ }^{16}$

The root causes of the conflict are political, originating in disputes about party leadership and direction, as well as unresolved divisions in the SPLM dating back to the country's independence war with Sudan, which saw a split in the then-rebel movement. ${ }^{17}$ However, battle lines have taken on ethnic contours, pitting the country's two largest groups, the Dinka and Nuer, against each other. With whole communities mobilised against each other, and gross human rights violations committed by both warring parties, the conflict has claimed upward of 6000 lives in just 12 months. ${ }^{18}$ The United Nations (UN) has claimed that as many as 9000 child soldiers have, in total, been recruited by both armed forces. ${ }^{19}$

The United Nations Mission in South Sudan (UNMISS), unprepared for the violence, has not been able to adequately fulfil its mandate of civilian protection: a base in Jonglei came under attack during the year, and by April civilians had been targeted and killed in and around five UNMISS bases. $^{20}$

It is estimated that about $70 \%$ of the army has either defected to the SPLM/A-IO or deserted, leaving government forces depleted. ${ }^{21}$ However, the opposition is not itself a unified force. Nuer militias and the Nuer White Army, for example, are responsible to their communities and thus not directly under control of the SPLM/A-IO, suggesting a weak chain of command in the group. ${ }^{22}$

The conflict has shown little sign of letting up. The Cessation of Hostilities agreement formed on 23 January 2014 was soon violated by both sides, as was a ceasefire agreement formed on 9 May. Soon after the parties missed the 10 August deadline for forming a transitional government, major hostilities resumed. At an Intergovernmental Agency for Development (IGAD)-convened summit held on 7 November, parties were to agree to abide by the earlier Cessation of Hostilities pact and form a transitional government. Instead, fighting resumed just days after.

Negotiations in December appeared to offer more hope: parties broadly agreed to a federal state structure, but could not reach consensus on key issues, including the power structure between the posts of president and prime minister, and security and economic reforms. ${ }^{23}$ In January 2015, IGAD released a statement condemning the heavy fighting that had broken out in Unity and Upper Nile states in the wake of the December negotiations. ${ }^{24}$

\section{The SPLM-N, the JEM, the SLA, and the SRF in Sudan}

In Sudan, home to one of the continent's deadliest conflicts in 2014, the government is waging war on two fronts: against rebels in Darfur, in the west of the country, and against the SPLMNorth (SPLM-N) in South Kordofan and Blue Nile states in the south.

Though the two conflicts are distinct, their origins have the same roots: exclusion from political power, and socio-economic marginalisation through the extraction of resources that benefit the political elite in Khartoum at the expense of local populations and their development. $^{25}$ 
The conflict in Darfur began in 2003 when the Justice and Equality Movement (JEM) and the Sudan Liberation Army (SLA) took up arms in protest at neglect from the central government. The government, in turn, launched a counter-insurgency initiative, sponsoring Arab militias (Janjaweed) to quell the rebellion. The conflict tapped into tensions between pastoralist and agrarian communities. Nomadic Arab communities affected by drought and desertification had begun to encroach on the territory of settled, agrarian Darfuris. Though Muslim themselves, the Janjaweed targeted the non-Arab Darfuris (the Fur, Zaghawa and Masalit) in a devastating campaign of ethnic cleansing through scorched-earth tactics and the looting and raiding of villages, often supported by air strikes. ${ }^{26}$

In South Kordofan - and later Blue Nile state - rebels who had fought for the independence of South Sudan began agitating against government prior to the secession of their southern neighbours from Sudan in 2011. According to the terms of the 2005 Comprehensive Peace Agreement (CPA) that paved the way for South Sudan's independence, South Kordofan and Blue Nile states were left north of the new border, with no opportunity for a referendum on self-determination. The 'popular consultations' mandated by the CPA were never properly concluded in Blue Nile, and never took place in South Kordofan, compounding local grievances. ${ }^{27}$ In 2011, the former SPLM/A rebels formed the SPLM-N in order to achieve a measure of political autonomy from central government, and secure political reform and a more even distribution of their region's oil riches. ${ }^{28}$

Between 2011 and 2014, 1,4 million civilians were displaced in South Kordofan and Blue Nile alone. In 2014, violence had not abated, claiming almost 4000 lives in the course of the year. Around 430000 civilians were displaced in Darfur in 2014 and roughly 240000 people in Blue Nile state are in need of humanitarian assistance. ${ }^{29}$

To date, there has been little movement in the direction of peace. The government paid lip service to inclusive dialogue relatively early on - President Omar al-Bashir launched a national dialogue process in early 2014 - and has steadfastly refused to meet Darfuri and SPLM-N rebels and unarmed opposition in a single, inclusive negotiation process.

Since 2011, the strongest rebel movements in Darfur - the JEM and the Minawei and Wahid factions of the SLA - and the SPLM-N have worked to unseat Bashir under the umbrella of the Sudan Revolutionary Front (SRF). However, the various rebel groups have not been able to ensure that same unity at the negotiating table. Throughout the peace process, Khartoum has insisted on separating out negotiations with Darfur and southern rebels, holding rounds of talks with the Darfuri groups in Doha, Qatar, and with the SPLM-N in Addis Ababa, Ethiopia.

The rebel groups have sought to strengthen their negotiating position, arguing for inclusive talks, given that solutions to the localised conflicts are national in nature and require political reform and transition to inclusive democracy in the single-party state.

In December, former South African president and the head of the African Union (AU) mediation team, Thabo Mbeki, suspended the latest round of negotiations between the government and the SPLM-N amid the two sides accusing each other of instigating a new round of fighting near South Kordofan's capital, Kaduqli. Similarly, Darfur peace talks were adjourned indefinitely, amid claims that the government had little interest in the peace process. $^{30}$ 


\section{Islamist terrorism}

The blatant attacks on civilians and security forces by Islamist groups Boko Haram and al-Shabaab in Nigeria and Somalia filled more newspaper column space in 2014 than any other conflict in sub-Saharan Africa during the course of the year.

The two groups espouse similar aims - the eradication of 'infidel' and Western influence, and the creation of states rooted in Islamic (Sharia) law - and they have traditionally pursued similar tactics in achieving these, including the targeting of government institutions, security forces and civilians through assassinations, bombings and other acts of terror.

\section{Boko Haram in Nigeria}

The Boko Haram insurgency was thought to have reached its peak in 2013, when the creation of a Joint Task Force comprising police and military forces, the rise of the Civilian Joint Task Force - a collection of vigilante groups focused on community protection - and a more concerted military offensive took a toll on the movement. However, the number of deaths attributed to the conflict tripled in 2014, and Human Rights Watch estimates that 1,5 million were displaced between May 2013 and September 2014. ${ }^{31}$

The group has proved itself adaptable, changing strategy over time. When Boko Haram turned to violence in 2009-10, it initially targeted security forces and politicians in attacks, but more recently expanded its classification of 'legitimate targets', ${ }^{32}$ conducting attacks in civilian spaces such as schools, churches and markets. ${ }^{33}$ Boko Haram has also practised scorched-earth policies in rural areas and high-profile kidnappings, with the abduction of around 270 girls from Chibok in April 2014 being the most widely publicised of these.

In the course of 2014, Boko Haram became adept at capturing and holding territory. By mid-September the group had taken 25 towns $^{34}$ and by November controlled swathes of territory, reportedly $20000 \mathrm{~km}^{2}$, in north-eastern Nigeria. By January 2015, after taking the city of Baga, the group was in effective control of Borno state's international borders with Cameroon, Chad and Niger, threatening the territorial integrity of the Nigerian state.

Boko Haram has fed off the failings of the state. Governance issues such as corruption, inadequate infrastructure, and poor provision of security, healthcare and educational services have bred animosity. In addition, inequitable divisions of wealth between north and south ${ }^{35}$ have created a fertile ground for recruitment from a sector of society marginalised from the economic benefits of Africa's wealthiest country. The impunity enjoyed by government forces in the north, which have been accused of indiscriminate extrajudicial killings, enforced disappearances and torture, ${ }^{36}$ has pushed individuals into the arms of the movement.

Boko Haram's capture of territory and large-scale attacks have proven it to be a military force to be reckoned with - but an indifferent government approach has also facilitated its rise. Attempts at reaching a political solution to the problem have failed, ${ }^{37}$ seemingly through a lack of political will. In late 2014 the government cancelled a deal in which the United States (US) would train a battalion of troops to fight the insurgent movement, purportedly because of a ban on US weapons sales based on Nigeria's poor human rights record. ${ }^{38}$ Furthermore, though the country has the financial resources to defeat the movement, much of the state's oil wealth is in the hands of a political elite removed from the conflict. ${ }^{39}$

Borno state senator Ahmed Zanna has attributed the government's sluggish response to the fact that attacks are largely focused on the economically marginalised north - its primary southern constituency is less directly affected. ${ }^{40}$ A New York Times report ${ }^{41}$ notes that 
President Goodluck Jonathan - who has been consistently slow in condemning the Boko Haram attacks ${ }^{42}$ - has treated the problem as a specifically northern one, and thus the responsibility of northern leaders.

Belated government attempts to contain the threat that Boko Haram poses to national security and territorial sovereignty have proved largely futile. The creation of the Joint Task Force and vigilante action in 2013 momentarily drove the group from the cities ${ }^{43}$ but in 2014 the fight returned to urban centres - with increased civilian targeting in response to vigilante action. Though the government has claimed success against Boko Haram in some operations, ${ }^{44}$ the poorly resourced and disillusioned armed forces are ill-equipped to wage war against a fragmented opposition with relatively independent, decentralised cells ${ }^{45}$ and members who are able to move freely in the region.

In the build-up to the 2015 elections, the Nigerian government faces a secondary challenge: communal tensions that threaten stability in the north and 'middle belt' of the country. Between January and July, 21 incidents of communal violence were recorded in the country, with roughly 900 casualties. ${ }^{46}$ In the volatile middle belt, communal tensions reside in overlapping ethnic and religious identities, which often map onto classifications of 'indigeneity'. ${ }^{47}$ According to the Global Centre for the Responsibility to Protect, Boko Haram's attacks - and the resultant displacement of people - may drive up these tensions, leading to an increase in inter-communal violence. ${ }^{48}$

\section{Al-Shabaab in Somalia}

In contrast to Boko Haram, Somalia's al-Shabaab has avoided direct clashes with state security forces in favour of guerrilla and terror tactics. The Islamist group reportedly relinquished as much as $85 \%$ of the territory it controlled after two African Union Mission in Somalia (AMISOM) offensives in 2014, and is said to have been pushed back to Jubba Valley in the south and Puntland in the north of the country. ${ }^{49}$

In March, the first AMISOM operation drove the group out of 10 south-central towns in just 20 days, ${ }^{50}$ while an offensive in late August saw al-Shabaab lose further territory, as well as control over the strategic port of Barawe. ${ }^{51}$ The group was also weakened by the assassination of its leader, Ahmed Abdi Godane, in a US drone attack in September.

Al-Shabaab has, however, retained its capacity for terror, launching attacks within and outside the borders of the country, taking a toll on local ${ }^{52}$ and foreign civilian populations. In July, for example, the group detonated a car bomb at the entrance to the Somali parliament, attacked the presidential palace and assassinated a Somali legislator; on 25 December eight militants attacked an AU base in Mogadishu. In late November the group killed 28 nonMuslims travelling on a bus in north-eastern Kenya, and shot and beheaded 36 labourers in the same region 10 days later.

The Kenyan attacks are indicative of al-Shabaab's political savvy. The group has carried out terror attacks in Kenya in retaliation for that country's intervention against al-Shabaab in Somalia but has, at the same time, sought sympathy for its cause by playing on the grievances of local Muslims who have been politically and economically marginalised and discriminated against by the government. ${ }^{53}$

The group is politically adept at home too. In presenting an Islamic agenda and framing its battle with the federal government and AMISOM in terms of historical attacks on Islam, al-Shabaab has tapped into the sentiments of a conservative Somali population. ${ }^{54}$ In contrast to the central government, which exercises little control outside of the capital and has proved 
unable to bring peace to the populace, the group has provided grassroots governance: according to think tank International Crisis Group (ICG), al-Shabaab, when in control of territory, has been able to present itself as a functional alternative to a dysfunctional government ${ }^{55}$ that, through lack of territorial authority and capacity, is unable to provide basic security and services. ${ }^{56}$ Where the Somali government, for example, has been unable to provide adequate education at a national level, al-Shabaab has upgraded Qu'ranic schools, in rural areas in particular; it has also been praised by Somalis for 'drilling boreholes, digging irrigation canals and building mosques and madrasas'. ${ }^{57}$

Furthermore, where the federal government is deeply divided on governance issues ${ }^{58}$ and absorbed by inter-clan politicking, ${ }^{59}$ al-Shabaab has retained a unified front and consistency in its objectives. ${ }^{60}$ Unlike the government, which has been weighed down by the internecine clan conflict that defines Somali politics, ${ }^{61}$ the group successfully navigates the complex world of these affiliations, using power imbalances and rural-urban divides between clans to its advantage. $^{62}$

\section{Trends and implications}

Across all conflicts, the escalation of attacks on civilians is of great concern. Non-combatants are not merely casualties of conflict crossfire - they are specifically targeted for political ends. In some cases, this amounts to civilian targeting because of an assumed identification with a rebel group based on shared race, ethnicity or religion; in others, attacks on civilians in campaigns of terror are simply a means by which to generate attention for a cause or as a show of force.

Of equal concern is the seeming difficulty of governments and the international community to secure the lives of civilians. Peacekeeping mandates compel regional and international forces to protect civilian lives, but the spread of conflict in states such as the CAR and Somalia makes such action difficult. Even when peacekeeping forces have been in close proximity to fighting, they have, at times, proved unable to safeguard civilian lives: in both the CAR and South Sudan civilians came under attack near - and even in - protected areas and peacekeeping bases. In Sudan, the government has made the protection of civilians almost impossible by preventing AU peacekeeping forces and humanitarian organisations from entering rebel territory.

That armed groups - government and rebel - are able to carry out such attacks with impunity damages public trust in both the institutions of government and in the international community. Importantly, it also drives local civilian populations to fill the security vacuum, arming themselves and forming self-defence units - units which may themselves become complicit in civilian targeting, particularly where conflicts play out along lines of identity.

The instrumental mobilisation of the ethnic and religious identities of communities to serve the purposes of existing and would-be political elites casts conflict in zero-sum terms. Activation of 'ethnic publics' shines an irreconcilable primordial light on a conflict in which individuals hold onto identities seen as threatened by - and fundamentally at odds with - the 'other'. Where, in reality, identities are fluid and multiple, conflicts that pit deeply held group identities against each other see the lines of those identities harden.

These fissures can lead to intractability in conflict. While the 'political entrepreneurs' who mobilise communal identities may be satisfied with political concessions in negotiation 
processes, the rigid lines of identity must be softened for sustainable peace to be achieved. This is not merely a matter of political representation in governments of national unity - such action may, in fact, be counterintuitive, giving permanence to social cleavages in the institutions of government - but of grassroots reconciliation efforts.

However, to cast conflicts in binary terms of identity is to ignore the deeper roots of political violence. The conflict in the CAR may present as conflict between Muslims and Christians; in South Sudan as Nuer versus Dinka; in Darfur as Arab against non-Arab; and in the case of Boko Haram and al-Shabaab as Islam versus Western influence - but to focus only on this is to miss the underlying causes. The state is the epicentre of conflict. The allocative institutions of state are the prize warring parties seek to claim, but the state also enables conflict, either through indifference, as in Nigeria, incapacity, as in the CAR, or, in the case of Sudan, actively engaging in conflict-creating activity.

Where the state is unable to deliver on the social contract - particularly in providing security to citizens - through weakness, a lack of inclusivity or a lack of territorial control, conditions favour a turn to conflict. Local warlords or communal groups fill the vacuum left by the state, garnering public support by stepping up to provide the services which the state is unable to provide. They may challenge the authority of the centre in a bid for political or resource access.

However much states may invest in peacekeeping operations to restore order, these can only put deeply ingrained conflicts on pause. Without a similar investment in building the institutions of state, inclusive democratic governance, vehicles for economic development and grassroots reconciliation, such initiatives are doomed to failure.

\section{Conclusion}

Elections loom large in Africa in 2015, with 15 slated to take place in the course of the year. ${ }^{63}$ Of these - in addition to the CAR, Nigeria, South Sudan and Sudan - Burkina Faso, Burundi, Cote d'Ivoire, and Lesotho have experienced political unrest in the recent past.

Though elections are considered an important step in the reconstruction of political order, Signé and Kpohazounde ${ }^{64}$ argue that going to the polls too soon after conflict may be counterproductive. The issue is not just about warring parties committing to a peaceful electoral process and outcome, but also creating conditions in which this is likely. This requires an environment in which the institutions of state have been sufficiently rebuilt to inspire public trust - particularly in the realm of security - where belligerents have disarmed, reconciliation efforts have been initiated, a credible electoral body is in place to manage elections, and political competition and participation are encouraged. ${ }^{65}$

In the CAR, South Sudan and Sudan it is not clear that such conditions are close to being met. Warring parties - or factions thereof - have not demonstrated a clear commitment to the democratic process by laying down arms or even agreeing on terms of elections. In the CAR, the institutions of state remain too weak to contain potential electoral violence; the warring parties in South Sudan have yet to reach agreement on what a new government would actually look like; and in Sudan, the ruling NCP has given no indication that elections will be an inclusive affair.

Rushing into elections may seem a panacea to violence, but they are unlikely, at this stage, to result in any form of sustainable peace. 
In Nigeria, the Boko Haram threat may inflame existing tensions. In a state with a de facto rotation of the presidency between north and south every eight years, southerner Goodluck Jonathan has been criticised for standing for re-election. ${ }^{66}$ His primary challenger, Muhammadu Buhari, is likely to garner most of his votes from the north of the country. However it is unclear, given violence and mass population displacement, ${ }^{67}$ that elections will go ahead in Yobe, Borno and Adamawa states. This may skew the outcome of the election in favour of Jonathan, calling the legitimacy of the vote into doubt, with the potential of triggering new violence.

\section{Notes}

1 ACLED, Trends in violence by country in 2014, www.acleddata.com/trends-in-violence-by-country-in-2014/, (accessed 15 January 2015).

2 Ibid.

3 ACLED, Rates of violence in 2014, www.acleddata.com/rates-of-violence-in-2014/, (accessed 13 January 2015).

4 Ibid.

5 ACLED, Violence against civilians in 2014, www.acleddata.com/violence-against-civilians-in-2014/, (accessed 13 January 2015).

6 USAID, Central African Republic - complex emergency (Factsheet no. 6), 21 February 2014, https://scms.usaid. gov/sites/default/files/documents/1866/car_ce_fs06_02-21-2014.pdf.

7 Central African Republic: Muslims trapped in enclaves, Human Rights Watch, 22 December 2014, www.hrw.org/ news/2014/12/22/central-african-republic-muslims-trapped-enclaves.

8 R2P monitor (Issue 18), New York, NY: Global Center for the Responsibility to Protect, 2014.

9 The Central African Republic's hidden conflict, Africa Briefing No. 105, Brussels: International Crisis Group (ICG), 2014.

10 Dhaffane had originally advocated for partition at the Brazzaville talks, but is said to have taken that demand off the table in return for a possible ministerial post; see K Agger, J Planer and H Dranginis, Seize the peace: four issues to target now in the CAR peace process, Washington, DC: Enough Project, 2014.

11 P Bouckaert, The unravelling: journey through the Central African Republic crisis, New York, NY: Human Rights Watch, 2014.

12 K Agger, J Planer and H Dranginis, Seize the peace: four issues to target now in the CAR peace process, Washington, DC: Enough Project, 2014.

13 Ibid.

14 Ibid.

15 The Central African Republic's hidden conflict, Africa Briefing No. 105, Brussels: ICG, 2014.

16 South Sudan: a civil war by any other name, Africa Report No. 217, Brussels: ICG, 2014.

17 Ibid.

18 ACLED puts the total at 6383 , but the figure is contested; the UN estimates that 'tens of thousands' have been killed, while the ICG says the number is at least 50 000; see D Smith, South Sudan marks first anniversary of civil war, The Guardian, 15 December 2014, www.theguardian.com/world/2014/dec/15/south-sudan-first-anniversarycivil-war.

19 Enough Project, Conflicts in South Sudan, 1 October 2014, www.enoughproject.org/conflicts/sudans/conflictssouth-sudan.

20 South Sudan: a civil war by any other name, Africa Report No. 217, Brussels: ICG, 2014.

21 Ibid.

22 Ibid.

23 TS Tekle, Sudan peace talks adjourned again amid fears of further violence, ZeHabesha, 22 December 2014, www. zehabesha.com/s-sudan-peace-talks-adjourned-again-amid-fears-of-further-violence/.

24 TS Tekle, IGAD condemns renewed violence in South Sudan, Sudan Tribune, 1 January 2015, www.sudantribune. com/spip.php?article53526. 
25 Thomson Reuters Foundation, Sudan conflicts, 4 November 2013, www.trust.org/spotlight/Sudan-conflicts; Thomson Reuters Foundation, Darfur conflict, 31 July 2014, www.trust.org/spotlight/darfur-conflict.

26 Sudan's spreading conflict (III): the limits of the Darfur peace process, Africa Report No. 211, Brussels: ICG, 2014.

27 A McCutchen, The Sudan Revolutionary Front: its formation and development, Geneva: Small Arms Survey, 2014.

28 Thomson Reuters Foundation, Sudan conflicts, 4 November 2013, www.trust.org/spotlight/Sudan-conflicts

29 R2P monitor (Issue 18), New York, NY: Global Center for the Responsibility to Protect, 2014.

30 Talks on Sudan's two areas collapse, fighting in South Kordofan, Radio Dabanga, 8 December 2014, https://www. dabangasudan.org/en/all-news/article/talks-on-sudan-s-two-areas-collapse-fighting-in-south-kordofan.

31 Letter to President Jonathan on the situation in Nigeria, Human Rights Watch, 25 September 2014, www.hrw.org/ news/2014/09/25/letter-president-jonathan-situation-nigeria.

32 ACLED, Real-time analysis of African political violence, Conflict Trends No. 33, January 2015, www.acleddata. com/research-and-publications/conflict-trends-reports/.

33 LP Blanchard, Nigeria's Boko Haram: frequently asked questions, 10 June 2014, https://fas.org/sgp/crs/row/ R43558.pdf.

34 Nigeria's dangerous 2015 elections: limiting the violence, Africa Report No. 220, Brussels: ICG, 2014.

35 About $72 \%$ of the northern population lives in conditions of poverty, compared with $27 \%$ in the south; see MA Sergie and T Johnson, Backgrounders: Boko Haram, 7 October 2014, www.cfr.org/nigeria/boko-haram/p25739.

36 Letter to President Jonathan on the situation in Nigeria, Human Rights Watch, 25 September 2014, www.hrw.org/ news/2014/09/25/letter-president-jonathan-situation-nigeria.

37 In October, the government announced a ceasefire and the possible negotiated release of the Chibok girls. Boko Haram denied the ceasefire and reportedly abducted around 60 women in Adamawa the next day; see A Nossiter, Boko Haram said to abduct more women in Nigeria, New York Times, 23 October 2014, www.nytimes.com/2014/ 10/24/world/africa/boko-harm-abducts-more-women-despite-claims-of-nigeria-cease-fire.html?_r=1.

38 Nigeria tells US to halt training of battalion, Associated Press, 1 December 2015, http://news.yahoo.com/nigeriatells-us-halt-training-battalion-164536406.html.

39 G York, Boko Haram insurgency exposes Nigeria's extreme economic inequality, The Globe \& Mail, 15 June 2014, www.theglobeandmail.com/news/world/boko-haram-insurgency-exposes-nigerias-extreme-economic-inequality/ article19175409/?page $=$ all $/$.

40 Ahmed Zanna: 'There is no political will to fight Boko Haram', Deutsche Welle, www.dw.de/ahmed-zanna-there-isno-political-will-to-fight-boko-haram/a-17641725, (accessed 18 January 2015).

41 A Okeowo, Inside the vigilante fight against Boko Haram, New York Times, 5 November 2014, www.nytimes.com/ 2014/11/09/magazine/inside-the-vigilante-fight-against-boko-haram.html?_r=0.

42 Including the kidnapping of the 'Chibok girls' and the recent Baga attacks; see Chibok community leader criticizes Jonathan over silence on abducted girls, Sahara Reporters, 16 January 2015, http://saharareporters.com/2015/01/16/ chibok-community-leader-criticizes-jonathan-over-silence-abducted-girls; D Magnowski and E Onu, Nigeria's Jonathan slams Paris attack, ignores Baga massacre, Bloomberg, 12 January 2015, www.bloomberg.com/news/201501-12/nigeria-s-jonathan-slams-islamist-raids-abroad-is-muted-at-home.html.

43 MA Sergie and T Johnson, Backgrounders: Boko Haram, 7 October 2014, www.cfr.org/nigeria/boko-haram/ p25739

44 In March, Nigeria claimed to have taken a major Boko Haram camp through coordinated ground-force operations and airstrikes; see F Soriwei, Soldiers attack B'Haram camp, seize 700 vehicles, Punch, 12 March 2014, www.punchng.com/news/soldiers-attack-bharam-camp-seize-700-vehicles/; S O'Grady, Cameroon launches first airstrikes against Boko Haram, Foreign Policy, 29 December 2014, http://foreignpolicy.com/2014/12/29/cameroonlaunches-first-airstrikes-against-boko-haram/.

45 Curbing the violence in Nigeria (II): the Boko Haram insurgency, Africa Report No. 216, Brussels: ICG, 2014.

46 The Central African Republic's hidden conflict, Africa Briefing No. 105, Brussels: ICG, 2014.

47 In Nigeria, groups that are not considered 'indigenous' often face discrimination and socio-economic marginalisation.

48 R2P monitor (Issue 18), New York, NY: Global Center for the Responsibility to Protect, 2014.

49 A Maasho, African Union says military still weakening Somalia's al Shabaab, Reuters, 7 January 2015, www.reuters. com/article/2015/01/07/us-somalia-insurgency-idUSKBN0KG18C20150107/.

50 Somalia: Al-Shabaab - it will be a long war, Africa Briefing No. 99, Brussels: ICG, 2014. 
51 The loss of Barawe was significant, as it enabled the flow of weapons into the country, as well as movement of local and foreign fighters; see GlobalSecurity.org, Al-Shabaab, www.globalsecurity.org/military/world/para/al-shabaab. htm, (accessed 16 January 2015).

52 According to the UN Office for the Coordination of Humanitarian Affairs (OCHA), roughly two thirds of Somalia's 7,1 million population had been displaced by November; 3,2 million were in need of humanitarian assistance, and more than 1 million required emergency food aid; see 2015 Humanitarian needs overview: Somalia, New York, NY: UN OCHA, 2014.

53 Kenya: Al-Shabaab - closer to home, Africa Briefing No. 102, Brussels: ICG, 2014.

54 Somalia: Al-Shabaab - it will be a long war, Africa Briefing No. 99, Brussels: ICG, 2014.

55 Ibid.

56 An estimated 3,2 million people are in need of emergency health services, while 2,8 million have insufficient access to water, sanitation and hygiene; see 2015 Humanitarian needs overview: Somalia, New York, NY: UN OCHA, 2014.

57 Somalia: Al-Shabaab - it will be a long war, Africa Briefing No. 99, Brussels: ICG, 2014, 17.

58 These include disagreements over governance structures and the role of Sharia in the state's justice system; see Somalia: Al-Shabaab - it will be a long war, Africa Briefing No. 99, Brussels: ICG, 2014.

59 After tussling with President Hassan Sheikh Mohamud, two prime ministers were dismissed by parliament in just over a year.

60 A rift in the organisation in 2013 saw Godane's leadership challenged, but it is argued that tensions were indicative of individual differences rather than a rift in ideological direction; see Somalia: Al-Shabaab - it will be a long war, Africa Briefing No. 99, Brussels: ICG, 2014.

61 A Samatar, Defeating al-Shabaab and dismembering Somalia, Al Jazeera, 1 July 2014, www.aljazeera.com/indepth/ opinion/2014/06/defeating-al-shabab-dismemberin-201463019484226147.html.

62 Somalia: Al-Shabaab - it will be a long war, Africa Briefing No. 99, Brussels: ICG, 2014.

63 Zambia's presidential election took place on 20 January. Elections are also set to take place in Burkina Faso, Burundi, the CAR, Chad, Cote d'Ivoire, Ethiopia, Guinea, Lesotho, Mauritius, Nigeria, Niger, South Sudan, Sudan, Tanzania and Togo; see National Democratic Institute, 2015-2016 elections calendar, www.ndi.org/ electionscalendar, (accessed 20 January 2015).

64 L Signé and G Kpohazounde, Where delaying elections can build peace, The Washington Post, 15 September 2014, www.washingtonpost.com/blogs/monkey-cage/wp/2014/09/15/where-delaying-elections-can-build-peace/.

65 Ibid.

66 Jonathan, then Nigeria's vice president, came to power in 2010 after the death of Umaru Yar'Adua, a northerner, in the third year of his term. With southerner Olusegun Obasanjo preceding Yar'Adua, and Jonathan running for election in 2011, northerners feel they have been done out of presidential representation; see H Murdock, Nigerians brace for elections amid north-south rift and Boko Haram, Christian Science Monitor, 27 September 2014, www.csmonitor.com/World/Africa/2014/0917/Nigerians-brace-for-elections-amid-north-south-rift-and-BokoHaram.

67 By Nigerian law, voters must cast ballots in their local constituencies. 